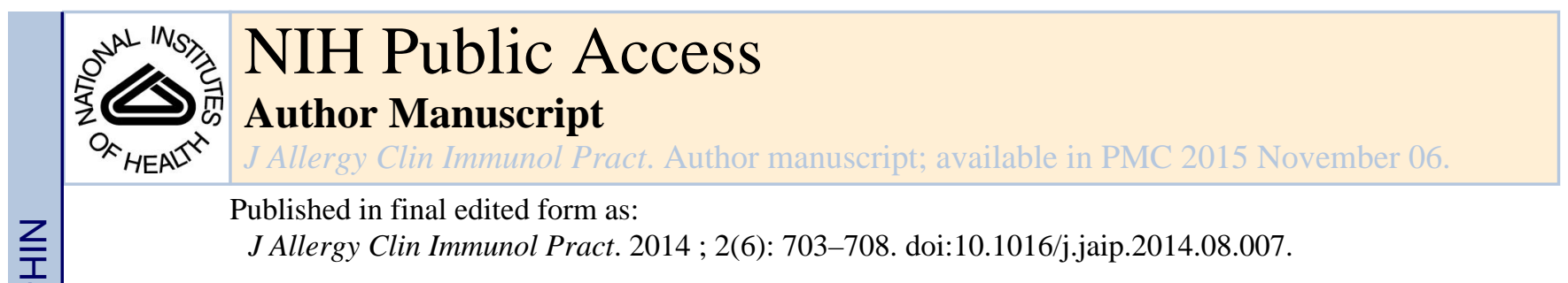

\title{
Allergic Bronchopulmonary Aspergillosis
}

Paul A. Greenberger, MDa, Robert K. Bush, MD ${ }^{b}$, Jeffrey G. Demain, MD ${ }^{c}$, Amber Luong, MD, PhD $^{d}$, Raymond G. Slavin, MD,MS ${ }^{e}$, and Alan P. Knutsen, MD $^{f}$

aDepartment of Medicine, Division of Allergy-Immunology, Northwestern University Feinberg School of Medicine

${ }^{b}$ Division of Allergy-Immunology, University of Wisconsin

'Allergy, Asthma \& Immunology Center of Alaska, University of Washington

dOtolaryngology-Head and Neck Surgery, University of Texas Medical School at Houston

eDepartment of Internal Medicine, Division of Infectious Diseases, Section of Allergy-Immunology, St. Louis University

fDivision of Allergy-Immunology, Department of Pediatrics, St. Louis University

\begin{abstract}
There remains lack of agreement on diagnostic criteria and approaches to treatment of patients with Allergic Bronchopulmonary Aspergillosis (ABPA). The results of a survey of AAAAI members regarding these 2 issues are presented and compared for concordance with published recommendations. The literature was reviewed for pertinent reports and an electronic survey was conducted of AAAAI members and fellows regarding diagnostic criteria, numbers of patients evaluated for ABPA, and treatment approaches. From 508 respondents to the survey sent to 5155 U. S. physicians in the AAAAI database of members and fellows, $245(48 \%)$ health professionals had treated at least 1 patient with ABPA in the previous year. For the diagnosis of ABPA, there was a difference in the threshold concentration of total serum IgE as $44.9 \%$ used $\geq 417 \mathrm{kU} / \mathrm{L}$ whereas $42.0 \%$ used $\geq 1000 \mathrm{kU} / \mathrm{L}$. These findings suggest that ABPA might be underdiagnosed. Regarding pharmacotherapy, oral steroids were recommended for $97.1 \%$ of patients and oral steroids + inhaled corticosteroids + anti-fungal agent were utilized in $41.2 \%$ of patients. The armamentarium for treatment of ABPA includes oral corticosteroids as the initial treatment with inhaled corticosteroids used for management of persistent asthma. Azoles remain adjunctive. Published experience with omalizumab has been limited.
\end{abstract}

\section{Keywords}

allergic; bronchopulmonary; aspergillosis; asthma; mycosis; IgE; azole

(C) 2014 American Academy of Allergy, Asthma amp; Immunology. All rights reserved

Corresponding Author: Paul A. Greenberger, MD, Division of Allergy-Immunology, Department of Medicine, Northwestern University Feinberg School of Medicine, Chicago IL, p-greenberger@ northwestern.edu, Phone: 312 695 4000, Fax: 3126954141.

Publisher's Disclaimer: This is a PDF file of an unedited manuscript that has been accepted for publication. As a service to our customers we are providing this early version of the manuscript. The manuscript will undergo copyediting, typesetting, and review of the resulting proof before it is published in its final citable form. Please note that during the production process errors may be discovered which could affect the content, and all legal disclaimers that apply to the journal pertain. 
The global prevalence of Allergic Bronchopulmonary Aspergillosis (ABPA) has been estimated to be as high as $2.5 \%{ }^{1}$, yet delays in diagnosis or undertreatment may lead to pulmonary fibrosis, bronchiectasis with chronic sputum production, and increasingly severe persistent asthma with loss of lung function. There are differences of opinion over the criteria for diagnosis, screening tests in patients with asthma, and how best to manage and treat the patient. ${ }^{2} \mathrm{ABPA}$ is almost always caused by Aspergillus fumigatus, which has intrinsic virulence, survival characteristics, pro-inflammatory actions, and enzymatic properties in susceptible hosts. The purpose of this review is to consider fungi implicated in Allergic Bronchopulmonary Mycoses, a brief discussion of the immunopathology, approaches to management and treatment, and report findings from a survey of allergistimmunologists in the AAAAI that explored the diagnostic criteria and treatments of ABPA.

\section{Allergic Bronchopulmonary Mycosis}

Since the original description of Allergic Bronchopulmonary Aspergillosis in $1952^{3}$, a number of other fungi or yeasts have been implicated as causing a similar clinical syndrome. Examples are listed in Table 1. Aspergillus fumigatus is by far responsible for the majority of these cases. But other fungi or yeasts have been identified when patients presented with features of ABPA (e.g., pulmonary infiltrates with peripheral blood eosinophils, +/bronchiectasis, underlying asthma) but lacked evidence of sensitization or recovery of Aspergillus fumigatus. The culprit fungus was identified in sputum or airway samples along with evidence of sensitization to the fungus by skin test or in vitro measurement. The diagnosis of ABPM therefore is predicated on the identification of fungi, other than $A$. fumigatus, by appropriate culture or molecular biology techniques in patients with clinical features of ABPA. Often there is repeated recovery of the rare fungus or yeast that leads to the diagnosis. Since commercially available reagents for skin testing and for in vitro methods to detect specific IgE antibodies are lacking for many of these fungi involved in ABPM, investigators need to prepare their own reagents or refer patients/samples to specialized centers for evaluation. It is likely that additional case reports of ABPM will appear due to the spectrum of fungi in the environment and the increasing prevalence of asthma.

\section{Criteria for Diagnosis of Allergic Bronchopulmonary Aspergillosis}

In a 2012 review in the Journal of Allergy and Clinical Immunology, the criteria for diagnosis were presented as follows: "The minimal criteria required for the diagnosis of ABPA are as follows: (1) asthma or CF with deterioration of lung function, (2) immediate Aspergillus species skin test reactivity, (3) total serum IgE level of $1000 \mathrm{ng} / \mathrm{mL}$ (416 IU/mL) or greater, (4) increased Aspergillus species-specific IgE and IgG antibodies, and (5) chest radiographic infiltrates. (See Table 2) Additional criteria might include peripheral blood eosinophilia, Aspergillus species serum precipitating antibodies, central bronchiectasis, and Aspergillus species-containing mucus plugs." 18

In 2003, the ABPA Consensus Conference of the Cystic Fibrosis Foundation ${ }^{19}$ proposed that ABPA be diagnosed for a classic case as follows: 1) acute or subacute clinical deterioration (increased cough, wheezing, exercise induced asthma, increased sputum, 
decrease in pulmonary function), 2) serum total IgE concentration $>1000 \mathrm{kU} / \mathrm{L}$ unless the patient is receiving systemic corticosteroids, 3 ) immediate cutaneous reactivity (prick skin test) to Aspergillus or presence of serum IgE-A. fumigatus, and 4) precipitating antibodies to A. fumigatus or serum IgG-A fumigatus. The minimal diagnostic criteria are 1) acute or subacute clinical deterioration (increased cough, wheezing, exercise induced asthma, increased sputum, decrease in pulmonary function), 2) serum total IgE concentration $>500$ $\mathrm{kU} / \mathrm{L}$, (If ABPA is suspected and the total serum IgE level is $200-500 \mathrm{kU} / \mathrm{L}$, repeat the total serum IgE in 1-3 months. If the patient is using oral corticosteroids, repeat the total serum IgE when steroid treatment has been discontinued. ${ }^{19}$ ) 3) immediate cutaneous reactivity (prick skin test) or presence of serum IgE122 A. fumigatus, 4) One of the following: a) precipitins to A. fumigatus or demonstration of IgG-A. fumigatus or b) new or recent abnormalities on chest radiography (infiltrates or mucus plugging) or chest $\mathrm{CT}$ (bronchiectasis) that has not cleared with antibiotics and standard physiotherapy. ${ }^{19}$

Potential diagnostic tools related to detection of fungal infection or colonization include findings from studies of invasive aspergillosis ${ }^{20}$ and cystic fibrosis ${ }^{21}$ consisting of enzyme assays for detection of antigenic side chains of Aspergillus galactomannan, ${ }^{20} 1,3-\beta-\mathrm{D}-$ glucan, which is the cell wall component of $A$ fumigatus and other fungi, ${ }^{20}$ and $A$ fumigatus DNA by PCR. ${ }^{20}$ The latter methodology detects viable and dead fungal organisms and inert spores. $^{21}$

\section{Genetic Risk Factors}

Genetic studies may provide potential aids in diagnosis and pathogenesis. For example, HLA-DR restriction has been shown to be a risk factor for the development of ABPA. Chauhan et $\mathrm{al}^{22-24}$ observed that patients with asthma and CF patients who expressed HLADR2 and/or DR5 but lacked HLA-DQ2 were at increased risk for ABPA after exposure to $A$. fumigatus. In particular, HLA-DR2 HLA-DRB1*1501 and HLA-DRB1*1503 genotypes were reported to provide high relative risk. Further studies indicated that the presence of HLA-DQ2, especially DQB1*0201, provided protection from the development of ABPA. Brouard et al ${ }^{25}$ reported that the $-1082 G G$ genotype of the IL-10 promoter was associated with colonization of A. fumigatus and the development of ABPA in CF. The - $1082 G G$ polymorphism has been associated with increased IL-10 synthesis; whereas the $-1082 \mathrm{~A}$ allele has lower IL-10 synthesis. Saxena et $\mathrm{al}^{26}$ reported that ABPA patients with polymorphisms (ala91 pro, arg94arg) in the collagen region of pulmonary surfactant protein A2 (SP-A2) had elevated total IgE concentrations and higher percentages of eosinophilia than observed in those patients who lacked the SNPs. They also found that $80 \%$ of patients carrying both alleles had ABPA $(\mathrm{P}=0.0079, \mathrm{OR}=10.4)$, while only $50 \%$ and $60 \%$ of patients carrying each allele, individually, were ABPA subjects, suggesting an additive effect. ${ }^{26}$ It is theorized that changes in conformation or affinity of SP-A2 may decrease these interactions and compromise host defense.

Miller et al ${ }^{27}$ examined mutations in the cystic fibrosis transmembrane conductance regulator gene (CFTR) in asthmatic subjects who did not have a diagnosis of cystic fibrosis. Mutations were present at a higher frequency in asthmatic patients who developed ABPA, 6 of $21(28.5 \%)$, versus control patients with asthma, 2 of 43 (4.6\%). These ABPA patients 
were heterozygous for the mutations. It is unclear what effect heterozygous CFTR mutations may have on mucus quality in airways of patients with asthma. Carvalho et $\mathrm{al}^{28}$ examined Toll-like receptor (TLR) polymorphisms of TLR2,TLR4 and TLR9 in cavitary pulmonary aspergillosis (CCPA), severe asthma associated with fungal sensitization (SAFS) and ABPA patients. ABPA patients had increased frequency of allele $\mathrm{C}$ for the TLR $9 \mathrm{~T}-1237 \mathrm{C}$ polymorphism compared to control patients. TLR-9 is a receptor that recognizes CpG motifs prevalent in bacterial and viral DNA. Novak et $\mathrm{al}^{29}$ reported that the TLR9 $\mathrm{C}$ allele of T-1237C decreases expression. Thus, decreased TLR-9 protective function may be an underlying susceptibility in the development of ABPA.

\section{Diagnostic Criteria by Allergist-Immunologists}

The results from a survey carried out by the AAAAI in 2012 are presented in Tables 3-5. Using the AAAAI's database of 5155 U. S. physicians, members and fellows were contacted on multiple occasions. (see Appendix 1 for the questionnaire). The response rate was $9.8 \%$ (508 physicians). Of these, 245 allergist-immunologists answered affirmatively to question 1 (Appendix 1) that they had seen a patient with ABPA in the past year and provided demographic information about their practice locations and range of patients with ABPA seen in the past year (Table 3). The range of diagnostic criteria used are presented in Table 4. There is an evenly divided difference between using the total IgE concentration of $\geq 417$ $\mathrm{IU} / \mathrm{mL}(\mathrm{kU} / \mathrm{L})$ by $44.9 \%$ and $\geq 1000 \mathrm{IU} / \mathrm{mL}(\mathrm{kU} / \mathrm{L})$ by $42 \%$ respondents respectively. In retrospect, some results may be attributable to the order of questions in the survey (Appendix 1, question 3 comes after both 1 and 2 and should have come after 1 to focus on ABPA and the same question coming after question 2 to focus on cystic fibrosis). Alternatively, because $83.7 \%$ of respondents referred to patients with ABPA, it is suspected that some of the difference in concentration of total IgE as a criterion does apply to ABPA). Bronchiectasis was a diagnostic criteria by $49.8 \%$ of the respondents. These data emphasize the need to clarify diagnostic criteria in order to increase (enhance) uniform application.

\section{Management of Allergic Bronchopulmonary Aspergillosis}

\section{Treatment Goals}

The overall goals are four-fold: 1) control of symptoms of asthma or cystic fibrosis (CF);2) prevent or treat pulmonary exacerbations of ABPA; 3 ) reduce or remit pulmonary inflammation; and 4) mitigate progression to end-stage fibrotic or cavitary disease (Table 6). Early and aggressive treatment of ABPA has the greatest likelihood of preventing progression to end-stage fibrotic lung disease (stage V). ${ }^{30-34}$ Following therapy, many patients with stage I (acute stage) and stage III (exacerbation stage) can enter complete remission, stage II, represented by a 35-50\% reduction in total serum IgE by 6 weeks, clearing of pulmonary infiltrates and symptomatic improvement. Unfortunately this may not be permanent, as some patients relapse and have additional pulmonary infiltrates. ${ }^{33-34}$ Earlier diagnosis and treatment appears to lower the risk of advancement to stage IV (glucocorticosteroid dependent) or stage V (fibrocavitary disease). ${ }^{34}$ 


\section{Exposure}

Bioaerosols of very large numbers of fungi (with bacteria and endotoxins) occur from disturbing organic waste and have been associated with ABPA in 2 of 28 garden waste collectors. ${ }^{35}$ We were unable to find evidence to make a strong recommendation to minimize exposure to fungi through avoidance and mitigation such as from moldy basements, water damaged buildings, saunas, and indoor areas with improper home ventilation. While these are prime locations for growth of molds ${ }^{36}$, and can be pertinent for patients with asthma and allergic rhinitis, there is a lack of evidence to make a strong recommendation regarding prevention of pulmonary infiltrates in ABPA.

\section{Therapeutics}

Oral Corticosteroids-Corticosteroids remain the mainstay in the management of ABPA, by targeting the inflammatory response triggered by A. fumigatus. ${ }^{34}$ Most patients with ABPA require periods of oral steroid treatment, followed by tapering doses. Dosing of oral steroids for ABPA has not been well defined. Lower dose oral steroids have been associated with a higher rate of relapse, whereas higher doses for longer duration have a higher remission rate. A common strategy ${ }^{34}$ is 2 weeks of daily prednisone $0.5 \mathrm{mg} / \mathrm{kg}$, followed by 6 to 8 weeks of alternate day therapy and then tapering by $5-10 \mathrm{mg}$ every 2 weeks. A more aggressive approach ${ }^{32,33}$ is prednisolone $0.75 \mathrm{mg} / \mathrm{kg} /$ day for 6 weeks, then $0.5 \mathrm{mg} / \mathrm{kg} /$ day for 6 weeks, followed by a tapering dose of $5 \mathrm{mg}$ every 6 weeks to continue for a total duration of 6 to 12 months.

Oral steroids are important in the control of symptoms and reducing the likelihood of relapse. Patients are considered in remission when they remain without pulmonary infiltrates/eosinophilia for 6 months after oral steroid withdrawal. ${ }^{34} \mathrm{~A}$ useful marker of disease activity and success of therapy is a total serum $\operatorname{IgE}$ concentration. Total serum $\operatorname{IgE}$ is monitored every 6 to 8 weeks after the initiation of oral steroids and continued for one year thereafter. The goal is to achieve a $35 \%$ to $50 \%$ reduction of total serum IgE, which leads to clinical and radiological improvement. Chest imaging, either by chest $x 219$ ray or high resolution chest CT, after 4 to 8 weeks of initiation of oral steroid therapy, is important to assess resolution of infiltration. Spirometry is also a useful tool to objectively assess response to therapy. ${ }^{30}$

Intravenous Corticosteroids-Pulse therapy with monthly intravenous methylprednisolone at a dose of $10-20 \mathrm{mg} / \mathrm{kg} /$ day for three consecutive days, in conjunction with itraconazole, has been demonstrated effective in both reduction in subjective symptoms as well as objective measurements. ${ }^{37,38}$ This may be a consideration in patients demonstrating resistance to oral therapy. A potent inhibitor of CYP3A4, itraconazole increases concentrations of methylprednisolone but not prednisolone and can cause suppression of cortisol secretion. ${ }^{39}$

Inhaled Corticosteroids-Inhaled corticosteroids are a central component in the management of persistent asthma; however in the dosage equivalent of 400-800 $\mu \mathrm{g}$ of beclomethasone dipropionate, when combined with a long acting beta agonist, they have not been shown to be effective in preventing increasing concentrations of total IgE. ${ }^{40}$ While 
symptoms of asthma were improved, they could not be controlled completely. ${ }^{40}$ The authors concluded that "High doses of ICS alone have no role in the management of ABPA-S and should not be used as first-line therapy." 40

\section{Antifungals}

Antifungals play an important, yet adjunctive role in the management of ABPA. Antifungals may reduce the requirement for prolonged high dose systemic corticosteroids by decreasing the burden of fungal colonization and attenuating inflammatory responses. The majority of the literature addressing antifungal therapy focuses on the use of Amphotericin and the azoles (ketoconazole, itraconazole, voriconazole and posaconazole). In recent years the use of Amphotericin B and ketoconazole has been replaced by antifungals with fewer potential side effects.

Itraconazole-Among the antifungals used to treat ABPA, itraconazole is the most commonly recommended. Itraconazole has been demonstrated to significantly reduce total serum IgE, sputum eosinophils and most importantly decrease symptoms and the oral steroid requirement. ${ }^{41,42}$ Itraconazole is recommended for those patients who are steroid dependent and for those that have relapse following course of steroids. The recommended adult dose for itraconazole is $200 \mathrm{mg}$ twice daily for 4 to 6 months and then tapered over the following 4 to 6 months. As noted earlier, it is important to note that itraconazole can inhibit the metabolism of methylprednisolone. Renal function and concurrent medication usage should also be monitored. As with most azoles, adverse drug reactions are not uncommon and include nausea and vomiting, diarrhea, flatulence, hyperlipidemia, hypokalemia and elevated liver enzymes. Phototoxicity and photosensitivity (UVA) have been reported. ${ }^{43}$ An alternative approach is for courses of 4-6 months. ${ }^{44,45}$ As with any antimicrobial agent, resistance to azoles is well known, and fungal sensitivities may need to be obtained in some patients. $^{*}$

Other Azoles-Voriconazole and posaconazole are reported to be an effective adjunct therapy in the management of ABPA with clinical improvement in $68 \%$ of patients with ABPA treated with voriconazole and $78 \%$ of ABPA patients treated with posaconazole. ${ }^{46}$ Side effect profiles were similar to itraconozole $40 \%$ of those treated with voriconazole and $22 \%$ of those with posaconazole. ${ }^{46}$ Dosing of voriconazole adult patients is $300-600 \mathrm{mg} / \mathrm{day}$ and posaconazole $880 \mathrm{mg} /$ day; adjusted by plasma monitoring. The target pre-dose voriconazole plasma level was $1.3-5.7 \mathrm{mg} / \mathrm{mL}$. The target posaconazole random plasma level was $>0.7 \mathrm{mg} / \mathrm{L} .{ }^{46}$ In patients who had failed to improve with itraconazole, at least $70 \%$ of patients, who tolerated either voriconazole or posaconazole, responded favorably. ${ }^{47}$

\section{Monoclonal Antibody Therapy}

There have been a few case reports demonstrating benefit of omalizumab in the management of ABPA, where some patients had concurrent cystic fibrosis. ${ }^{48-50} \mathrm{~A}$ trial of omalizumab in 16 patients with asthma and ABPA, demonstrated significant reductions in exacerbations

*University of Texas Health Sciences Center at San Antonio, Department of Pathology, 7703 Floyd Curl Drive, MC 7750, Room 329E, San Antonio, TX 78229-3900. Ph: 210567 4131, Fax: 2105674076 
and steroid requirement, although did not demonstrate improvement in spirometry. ${ }^{51}$

Reduction in exacerbations of asthma and oral steroid requirements have been reported by others. ${ }^{52}$ This potential adjunct in ABPA management, with a low side effect profile, warrants double blind, randomized, controlled trials. The role of treatment with antibodies to IL-4Ra (dupilumab), IL-5 (mepolizumab), IL-13 (lebrikizumab) or other targets in ABPA remains speculative.

\section{Treatments and Tests by Allergist-Immunologists}

The AAAAI survey results regarding treatment and testing approaches are presented in Table 5. Oral corticosteroids with or without inhaled corticosteroids were administered by $97 \%$ of the respondents. Antifungals plus corticosteroids were utilized by $41 \%$ of respondents. The distribution of medications or their combinations could reflect varying stages of ABPA (pulmonary infiltrates or none), repetitive expectoration of sputum plugs or none, ease or difficulty of treatment of concomitant asthma or ABPA, and physician and patient preferences among other explanations.

\section{Summary}

As the worldwide prevalence of asthma has increased, it appears that the prevalence of ABPA also has increased. Thus, ABPA is no longer a rare condition and has been recognized as specific subtype (endotype) of asthma. ${ }^{53}$ The results of the study of allergistimmunologists in the AAAAI suggest that uniform criteria for diagnosis are needed, especially as to the cut-off of total $\operatorname{IgE}$ concentration (and the appropriate units (eg kU/L, $\mathrm{IU} / \mathrm{mL}$ in which it is expressed), and that controlled trials would be informative to understand the place in therapy of all of the therapies that are employed. Establishing separate registries of patients with ABPA with asthma and with cystic fibrosis in terms of risk factors, exposures, and diagnostic criteria and treatment, would provide valuable information in better understanding and treating ABPA.

\section{Supplementary Material}

Refer to Web version on PubMed Central for supplementary material.

\section{Acknowledgements}

a....supported by the Ernest S. Bazley Grant to Northwestern University and Northwestern Memorial Hospital

d....supported by the National Institutes of Health Clinical and Translational Award UL1 TR000371, the National Center for Advancing Translational Research Award KL2 TR000370 and The Triological Society Research Career Development Award

\section{Abbreviations}

ABPA Allergic Bronchopulmonary Aspergillosis

ABPM Allergic Bronchopulmonary Mycosis

CCPA Chronic cavitary Pulmonary Aspergillosis 


$\begin{array}{ll}\text { CF } & \text { Cystic Fibrosis } \\ \text { CFTR } & \text { Cystic Fibrosis transmembrane conductance regulator } \\ \text { SAFS } & \text { Severe asthma associated with fungal sensitization } \\ \text { SP-A2 } & \text { Surfactant protein A2 } \\ \text { TLR } & \text { Toll-like receptor }\end{array}$

\section{References}

1. Denning DW, Pleuvy A, Cole DC. Global burden of allergic bronchopulmonary aspergillosis with asthma and its complication chronic pulmonary aspergillosis in adults. Med Mycol. 2013; 51:361370. [PubMed: 23210682]

2. Greenberger PA. Went to suspect and work up allergic bronchopulmonary aspergillosis. Ann Allergy Asthma Immunol. 2013; 111:1-4. [PubMed: 23806451]

3. Hinson KFW, Moon AJ, Plummer NS. Bronchopulmonary aspergillosis: a review and report of eight new cases. Thorax. 1952; 7:317-333. [PubMed: 13015523]

4. Greenberger PA. Allergic bronchopulmonary aspergillosis and fungoses. Clin Chest Med. 1988; 9:599-608. [PubMed: 3069291]

5. Akiyama K, Takizawa H, Suzuki M, Miyachi S, Ichinohe M, Yanagihara Y. Allergic bronchopulmonary aspergillosis due to Aspergillus oryzae. Chest. 1987; 91:2856.

6. Elliott MW, Newman-Taylor AJ. Allergic bronchopulmonary aspergillosis. Clin Exp Allergy. 1997; 27(Suppl 1):55-59. [PubMed: 9179446]

7. Chowdhary A, Agarwal K, Randhawa HS, Kathuria S, Gaur SN, Najafzadeh MJ, et al. A rare case of allergic bronchopulmonary mycosis caused by Alternaria alternata. Med Mycol. 2012; 50:890896. [PubMed: 22563857]

8. McAleer R, Kroenert DB, Elder JL, Froudist JH. Allergic bronchopulmonary disease caused by Curvularia lunata and Drechslera hawaiiensis. Thorax. 1981; 36:338-344. [PubMed: 7314001]

9. Akiyama K, Mathison DA, Riker JB, Greenberger PA, Patterson R. Allergic bronchopulmonary Candidiasis. Chest. 1984; 85:699-701. [PubMed: 6370621]

10. Arora A, Huffnagle GB. Immune regulation during allergic bronchopulmonary mycosis: Lessons taught by two fungi. Immunol Res. 2005; 33:53-68. [PubMed: 16120972]

11. Halwig JM, Brueske DA, Greenberger PA, Dreisin RB, Sommers HM. Allergic Bronchopulmonary Curvulariosis. Am Rev Respir Dis. 1985; 132:186-188. [PubMed: 4040344]

12. Backman KS, Roberts M, Patterson R. Allergic bronchopulmonary mycosis caused by Fusarium vasinfectum. Am J Respir Crit Care Med. 1995; 152:1379-1381. [PubMed: 7551398]

13. Hendrich DJ, Ellithrope DB, Lyon F, Hattier P, Salvaggio JE. Allergic bronchopulmonary helminthosporiosis. Am Rev Respir Dis. 1982; 126:935-938. [PubMed: 6890783]

14. Ogawa H, Fujimura M, Tofuku Y. Allergic bronchopulmonary fungal disease caused by Saccharomyces cerevisiae. J Asthma. 2004; 41:223-228. [PubMed: 15115175]

15. Kamei K, Unno H, Nagao K, Kuriyama T, Nishimura K, Miyaji M. Allergic bronchopulmonary mycosis caused by the basidiomycetous fungus Schizophyllum commune. Clin Infect Dis. 1994; 18:305-309. [PubMed: 8011808]

16. Benatar SR, Allan B, Hewitson RP. Allergic bronchopulmonary stemphyliosis. Thorax. 1980; 35:515-518. [PubMed: 7192017]

17. Patterson R, Samuels BS, Phair JJ, Roberts M. Bronchopulmonary Torulopsosis. Int Arch Allergy Appl Immunol. 1982; 69:30-33. [PubMed: 7201980]

18. Knutsen AP, Bush RK, Demain JG, Denning DW, Dixit A, Fairs A, et al. Fungi and allergic lower respiratory tract diseases. J Allergy Clin Immunol. 2012; 129:280-291. [PubMed: 22284927] 
19. Stevens DA, Moss RB, Kurup VP, Knutsen AP, Greenberger PA, Judson MA, et al. Allergic bronchopulmonary aspergillosis in cystic fibrosis - state of the art: Cystic Fibrosis Foundation Consensus Conference. Clin Infect Dis. 2003; 37(Suppl 3):S 225-S 264.

20. Mennink-Kersten MASH, Ruegebrink D, Wasei N, Melchers WJG, Verweij PE. In vitro release by Aspergillus fumigatus of galactofuranose antigens, 1,3- $\beta$-D-glucan, and DNA, surrogate markers used for diagnosis of invasive aspergillosis. J Clin Microbiol. 2006; 44:1711-1718. [PubMed: 16672397]

21. Baxter CG, Moore CB, Jones AM, Webb AK, Denning DW. IgE-mediated immune responses and airway detection of Aspergillus and Candida in adult cystic fibrosis. Chest. 2013; 143:1351-1357. [PubMed: 23139075]

22. Chauhan BA, Knutsen AP, Hutcheson PS, Slavin RG, Bellone CJ. T cell subsets, epitope mapping, and HLA-restriction in patients with allergic bronchopulmonary aspergillosis. J Clin Invest. 1996; 97:2324-3231. [PubMed: 8636413]

23. Chauhan B, Santiago L, Kirschmann DA, Hauptfeld V, Knutsen AP, Hutcheson PS, et al. The association of HLA-DR alleles and T cell activation with allergic bronchopulmonary aspergillosis. J Immunol. 1997; 159:4072-4076. [PubMed: 9378997]

24. Chauhan B, Santiago L, Hutcheson PS, Schwartz HJ, Spitznagel E, Castro M, et al. Evidence for the involvement of two different MHC class II regions in susceptibility or protection in allergic bronchopulmonary aspergillosis. J Allergy Clin Immunol. 2000; 106:723-729. [PubMed: 11031343]

25. Brourad J, Knauer N, Boelle P-Y, Corvol H, Henrion-Caude A, Flamant C, et al. Influence of interleukin-10 on airways colonization by Aspergillus fumigatus in cystic fibrosis patients. J Infect Dis. 2005; 191:1988-1991. [PubMed: 15871134]

26. Saxena S, Madan T, Shah A, Muralidhar K, Sarma PA. Association of polymorphisms in the collagen region of SP-A2 with increased levels of total IgE antibodies and eosinophilia in patients with allergic bronchopulmonary aspergillosis. J Allergy Clin Immunol. 2003; 111:1001-1007. [PubMed: 12743564]

27. Miller PW, Hamosh A, Macej M Jr, Greenberger PA, MacLean J, Walden SM, et al. Cystic fibrosis transmembrane conductance regulator (CFTR) gene mutations in allergic bronchopulmonary aspergillosis. Am J Hum Genet. 1996; 59:45-51. [PubMed: 8659542]

28. Carvalho A, Pasqualotto AC, Pitzurra L, Romani L, Denning DW, Rodrigues F. Polymorphisms in toll-like receptor genes and susceptibility to pulmonary aspergillosis. J Infect Dis. 2008; 197:618621. [PubMed: 18275280]

29. Novak N, Yu CF, Bussmann C, Maintz L, Peng WM, Hart J, et al. Putative association of a TLR9 promoter polymorphism with atopic eczema. Allergy. 2007; 62:766-772. [PubMed: 17573724]

30. Mahdavinia M, Grammer LC. Management of allergic bronchopulmonary aspergillosis: a review and update. Ther Adv Respir Dis. 2012; 6(3):173-187. [PubMed: 22547692]

31. Bains SN, Judson MA. Allergic bronchopulmonary aspergillosis. Clin Chest Med. 2012; 33:265281. [PubMed: 22640845]

32. Agawal R. Allergic bronchopulmonary aspergillosis. Chest. 2009; 135:805-826. [PubMed: 19265090]

33. Agarwal R, Gupta D, Agarwal AN, et al. Allergic bronchopulmonary aspergillosis: lessons from 126 patients attending chest clinic in north India. Chest. 2006; 130:442-448. [PubMed: 16899843]

34. Greenberger PA. Allergic bronchopulmonary aspergillosis. J Allergy Clin Immunol. 2002; 110:685-692. [PubMed: 12417875]

35. Poole CJM, Wong M. Allergic bronchopulmonary aspergillosis in garden waste (compost) collectors-occupational implications. Occupational Med. 2103; 63:517-519.

36. [last accessed: 10/7/2012] Molds in the environment. CDC website: www.cdc.gov/mold/faq.htm

37. Thompson JM, Wesley A, Byrnes CA, et al. Pulse intravenous methylprednisolone for resistant allergic bronchopulmonary aspergillosis in cystic fibrosis. Pediatr Pulmonol. 2006; 41(2):164-170. [PubMed: 16317722]

38. Cohen-Cymbesknah M, Blace H, Shoseyov D, et al. Intravenous monthly pulse methylprednisolone treatment for ABPA in patients with cystic fibrosis. J Cyst Fibros. 2009; 8(4): 253-257. [PubMed: 19447081] 
39. Lebrun-Vignes B, Corbrion Archer V, Diquet B, Levron JC, Chosidow O, Puech AJ, et al. Effect of itraconazole on the pharmacokinetics of prednisone and methylprednisolone and cortisol secretion in healthy subjects. Br J Clin Pharmacol. 2001; 51:443-450. [PubMed: 11422002]

40. Agarwal R, Khan A, Aggarwal AN, Saikia B, Gupta D, Chakrabarti A. Role of inhaled corticosteroids in the management of serological Allergic Bronchopulmonary Aspergillosis (ABPA). Intern Med. 2011; 50:855-860. [PubMed: 21498933]

41. Wark PA, Hensley MJ, Saltos N, et al. Antiinflammatory effect of itraconazole on stable allergic bronchopulmonary aspergillosis; a randomized control trial. J Allergy Clin Immnol. 2003; 111:952-957.

42. Wark PA, Gibson PG, Wilson AJ. Azoles for allergic bronchopulmonary aspergillosis associated with asthma. Cochrane Database Syst Rev. 2004 CD001108.

43. Haylett AK, Felton S, Denning DW, Rhodes LE. Voriconazole-induced photosensitivity: photobiological assessment of a case series of 12 patients. Br J Dermatol. 2012; 168:179-185. [PubMed: 22860570]

44. Agarwal R, Chakrabarti A, Shah A, Gupta D, Meis JF, Guleria R, et al. Allergic bronchopulmonary aspergillosis: Review of literature and proposal of a new diagnostic and classification criteria. Clin Exp Allergy. 2013; 43:850-873. [PubMed: 23889240]

45. Hogan C, Denning DW. Allergic bronchopulmonary aspergillosis and related allergy syndromes. Semin Resp Crit Care Med. 2011; 32:682-692.

46. Livingston L, Niven RM, Cooley J, Denning DW. Voriconazole and posaconazole improve asthma severity in allergic bronchopulmonary aspergillosis and severe asthma with fungal sensitization. $\mathrm{J}$ Asthma. 2012; 49(4):423-433. [PubMed: 22380765]

47. Chrishimba L, Niven RM, Cooley J, Denning DW. Voriconazole and posaconazole improve asthma severity in allergic bronchopulmonary aspergillosis and severe asthma with fungal sensitization. J Asthma. 2012; 49:423-433. [PubMed: 22380765]

48. Lebecque P, Leonard A, Pileete C. Omalizumab for treatment of allergic bronchopulmonary aspergillosis exacerbations in cystic fibrosis patients. Peditr Pulmonol. 2009; 44:546.

49. Kanu A, Patel K. Treatment of allergic bronchopulmonary aspergillosis with cystic fibrosis with anti- IgE Antibody (omalizumab). Pediatr Pulmonol. 2008; 43:1249-1251. [PubMed: 19009619]

50. van der Ent CK, Hoestra H, Rijkers GT, et al. Successful treatment of ABPA with recombinant anti-IgE antibody. Thorax. 2007; 62:267-277.

51. Tille-Lelond I, Germaud P, Leroyer C, et al. Allergic bronchopulmonary aspergillosis and omalizumab. Allergy. 2011; 66:1254-1256. [PubMed: 21517902]

52. Moss RB. The use of biologic agents for the treatment of fungal asthma and allergic bronchopulmonary aspergillosis. Ann N. Y. Acad Sci. 2012; 1272:49-57. [PubMed: 23231714]

53. Lotvall J, Akdis CA, Bacharier LB, Bjermer L, Casale TB, Custovic A, et al. Asthma endotypes: a new approach to classification of disease entities within the asthma syndrome. J Allergy Clin Immunol. 2011; 127:355-360. [PubMed: 21281866] 


\section{Table 1}

Fungi Associated with Allergic Bronchopulmonary Mycoses

\begin{tabular}{|c|c|}
\hline Organism & Reference \\
\hline Aspergillus fumigatus & Hinson et al, $1952^{3}$ \\
\hline Aspergillus ochraceus & Greenberger, $1988^{4}$ \\
\hline Aspergillus oryzae & Akiyama, at al. $1987^{5}$ \\
\hline Aspergillus terreus & Elliott et al, $1997^{6}$ \\
\hline Alternaria alternata & Chowdhary et al, $2012^{7}$ \\
\hline Bipolaris (Dreschleria) hawaiiensis & McAleer et al, $1981^{8}$ \\
\hline Candida albicans & Akiyama et al, $1984^{9}$ \\
\hline Cryptococcus neoformans & Arora et al, $2005^{10}$ \\
\hline Curvularia lunata & Halwig et al, $1985^{11}$ \\
\hline Fusarium vasinfectum & Backman et al, $1995^{12}$ \\
\hline Geotricum candidum & Elliott et al, $1997^{6}$ \\
\hline Helminthosporium species & Hendrich DJ, et al $1982^{13}$ \\
\hline Penicillium species & Elliott et al, $1997^{6}$ \\
\hline Peudoallescheria boydii & Elliott et al, $1997^{6}$ \\
\hline Sacchromycetes cerevisiae & Ogawa et al, $2004^{14}$ \\
\hline Schizophyllum commune & Kamei K et al, $1994^{15}$ \\
\hline Stemphyllium lanuginosum & Benatar et al, $1980^{16}$ \\
\hline Torulopsus glabrata (now designated Candida glabrata) & Patterson et al, $1982^{17}$ \\
\hline
\end{tabular}




\section{Table 2}

\section{Diagnostic Criteria for Allergic Bronchopulmonary Aspergillosis in Patients with Asthma or Cystic Fibrosis}

Patients with Asthma or Cystic Fibrosis (2012 Criteria in JACI ${ }^{18}$ )

Asthma or if Cystic Fibrosis, with deterioration of lung function

Immediate skin reactivity to Aspergillus species

Total serum IgE $\geq 1000 \mathrm{ng} / \mathrm{mL}(416 \mathrm{IU} / \mathrm{mL}) *$

Increased Aspergillus species-specific IgE and $\operatorname{IgG}$ antibodies

Chest roentgenographic infiltrates

"Additional criteria might include peripheral blood eosinophilia, Aspergillus species serum precipitating antibodies, central bronchiectasis, and Aspergillus species-containing mucus plugs"

ABPA Consensus Conference of the Cystic Fibrosis Foundation $\left(2003^{19}\right)$

Acute or subacute clinical deterioration (increased cough, wheezing, exercise induced asthma, increased sputum, decrease in pulmonary function)

Total serum IgE concentration $>1000 \mathrm{kU} / \mathrm{L}$ unless the patient is receiving systemic corticosteroids

Immediate cutaneous reactivity (prick skin test) to Aspergillus or presence of serum IgE-A. fumigatus

Precipitating antibodies to A. fumigatus or serum IgG-A. fumigatus

If the total serum IgE concentration is $>500$ but $\leq 1000$, then repeat it especially if the patient no longer requires oral corticosteroids. See text for criteria when the total IgE is $200-500 \mathrm{kU} / \mathrm{L}$.

${ }^{*} \mathrm{IU} / \mathrm{mL}=1 \mathrm{kU} / \mathrm{L}=2.4 \mathrm{ng} / \mathrm{mL}$ 
Table 3

Patients and practice settings of 508 allergist-immunologists who completed a survey about their allergic bronchopulmonary aspergillosis (ABPA) patients

\begin{tabular}{lc}
\hline & Results number (\%) \\
PATIENTS & \\
\hline ABPA patients & $263(51.8 \%)$ \\
No & $245(48.2 \%)$ \\
Yes & $205(83.7 \%)$ \\
Patients with asthma with ABPA & $214(87.3 \%)$ \\
$1-5$ patients & $23(9.4 \%)$ \\
$6-10$ patients & $8(3.3 \%)$ \\
$>11$ patients & $40(16.3 \%)$ \\
Patients with Cystic Fibrosis with ABPA & $36(14.7 \%)$ \\
$1-5$ patients & $3(1.2 \%)$ \\
$6-10$ patients & $1(0.4 \%)$ \\
$>11$ patients & $9(3.7 \%)$ \\
PRACTICE SETTING OF PHYSICIANS WITH ABPA PATIENTS \\
Rural area \\
Metropolitan area population \\
$<100,000$ & $33(13.5 \%)$ \\
$100-999,000$ & $84(34.3 \%)$ \\
$>1,000,000$ & $116(47.3 \%)$ \\
Missing & $3(1.2 \%)$ \\
\hline
\end{tabular}




\section{Table 4}

Diagnostic criteria used by 245 allergist-immunologists who diagnosed allergic bronchopulmonary aspergillosis in the past year

\begin{tabular}{lc}
\hline Study & Patients or Number (\%) \\
\hline Asthmatic patients with ABPA & $205(83.7 \%)$ \\
Cystic Fibrosis patients with ABPA & $40(16.3 \%)$ \\
Aspergilus fumigatus prick skin test (PST) & $188(76.7 \%)$ \\
Aspergillus fumigatus intradermal skin test (IDST) & $104(42.4 \%)$ \\
Anti-Aspergillus fumigatus IgE & $157(64.1 \%)$ \\
PST/ IDST/anti-Aspergillus fumigatus IgE & $231(94.3 \%)$ \\
Aspergillus fumigatus precipitins & $127(51.8 \%)$ \\
Anti-Aspergillus fumigatus IgG & $99(40.4 \%)$ \\
Af precipitins/ Anti-Aspergillus fumigatus IgG & $175(71.4 \%)$ \\
Total IgE $\geq 417$ IU/ml & $110(44.9 \%)$ \\
Total IgE $\geq 1000$ IU/ml & $103(42.0 \%)$ \\
Peripheral Blood Eosinophils $\geq 400 / \mu \mathrm{L}$ & $54(22.0 \%)$ \\
Bronchiectasis & $122(49.8 \%)$ \\
\hline
\end{tabular}


Table 5

Medications/Testing by 245 allergist-immunologists for patients with allergic bronchopulmonary aspergillosis in the past year

\begin{tabular}{lc}
\hline Treatment or Test & Patients, number (\%) \\
\hline OCS & $238(97.1 \%)$ \\
OCS + ICS & $124(50.6 \%)$ \\
OCS, no ICS & $26(10.6 \%)$ \\
Anti-fungal alone & $3(1.2 \%)$ \\
OCS/ICS + anti-fungal & $101(41.2 \%)$ \\
Voriconazole and/or posiconazole & $65(26.5 \%)$ \\
Omalizumab & $23(9.4 \%)$ \\
ACTH stimulation test & \\
1 month & $13(5.3 \%)$ \\
3-6 months & $36(14.7 \%)$ \\
\hline
\end{tabular}

OCS: oral corticosteroid

ICS: inhaled corticosteroid 
Table 6

Stages of allergic bronchopulmonary aspergillosis in patients with asthma

\begin{tabular}{|c|c|c|}
\hline Stage & $\begin{array}{l}\text { Radiography on Chest Roentgenogram } \\
\text { or CT Lungs (examples) }\end{array}$ & Total IgE Concentration \\
\hline \multicolumn{3}{|l|}{ I } \\
\hline (Acute) & $\begin{array}{l}\text { Homogeneous infiltrates, mucus plugging, Consolidation or lobar } \\
\text { collapse, "tree-in-bud" findings, bronchiectasis }\end{array}$ & Elevated \\
\hline \multicolumn{3}{|l|}{ II } \\
\hline (Remission) & No infiltrates & $\begin{array}{l}\text { Normal or elevated but less than in Stage } \\
\text { I }\end{array}$ \\
\hline \multicolumn{3}{|l|}{ III } \\
\hline (Exacerbation) & As in stage 1 & Elevated (double that of Stage 2) \\
\hline \multicolumn{3}{|l|}{ IV } \\
\hline (Steroid dependent asthma) & $\begin{array}{l}\text { No infiltrates, can have atelectasis or hyperinflation from asthma } \\
\text { (if an exacerbation occurs, pulmonary infiltrates such as in stage } 1 \\
\text { can be present) }\end{array}$ & Elevated or normal \\
\hline \multicolumn{3}{|l|}{$\mathrm{V}$} \\
\hline (End Stage Fibrotic) & $\begin{array}{l}\text { Scarring, hyperinflation, chronic infiltrates, fibrosis or cavities or } \\
\text { fibrocavitary findings }\end{array}$ & Normal or elevated \\
\hline
\end{tabular}

